\title{
Corrigendum: NFkB1 is a suppressor of neutrophil-driven hepatocellular carcinoma
}

C.L. Wilson, D. Jurk, N. Fullard, P. Banks, A. Page, S. Luli, A.M. Elsharkawy, R.G. Gieling, J. Bagchi Chakraborty, C. Fox, C. Richardson, K. Callaghan, G.E. Blair, N. Fox, A. Lagnado, J.F. Passos, A.J. Moore, G.R. Smith, D.G. Tiniakos, J. Mann, F. Oakley \& D.A. Mann

Nature Communications 6:6818 doi: 10.1038/ncomms7818 (2015); Published 16 Apr 2015; Updated 21 Sep 2015

The diagram in Supplementary Fig. 6a illustrating the targeting strategy for the $n f k b 1^{\mathrm{S} 340 \mathrm{~A}} \mathrm{KI}$ allele depicts an unrelated targeting strategy. The correct version of the figure appears below. 
a

Wildtype Allele

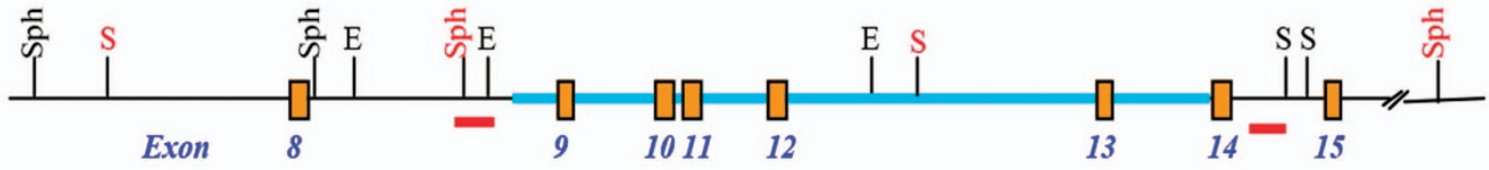

\section{Recombinant Allele}

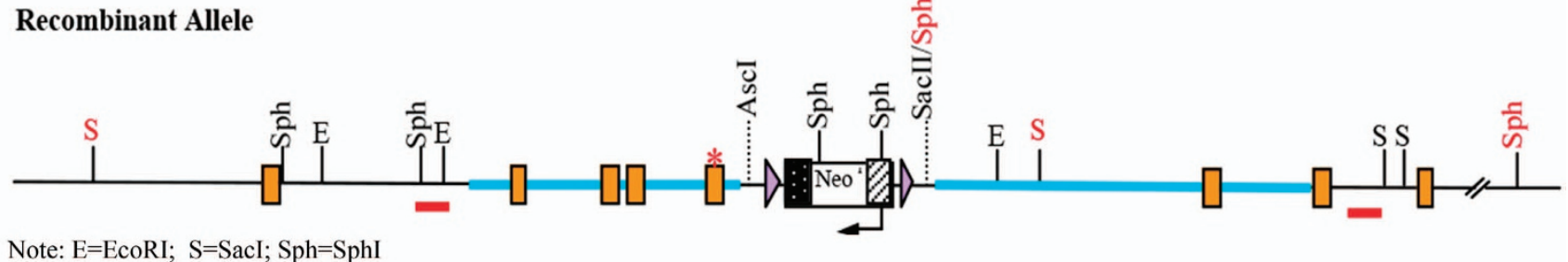

Note: $\mathrm{E}=\mathrm{EcoRI} ; \mathrm{S}=\mathrm{SacI} ; \mathrm{Sph}=\mathrm{SphI}$

$$
1 \mathrm{~kb} \quad \mathrm{~L} \text { LoxP } \mathrm{G} \mathrm{Frt}=\text { Homology arm }- \text { Probe } \square \text { Exon } * \text { S340A Mutation }
$$

b

The pups from chimera breedings were screened by the following PCR assay.

Primers:

NFkB1S340A knock-in F: Tm=60.6

5'- GTCTTCAAAACGCCAAAGTATAAGGATGTC - 3'

NFkB1S340A knock-in R: Tm=61.2

$5^{\prime}$ - CCCCTCCTGGTGGAGGACCAC - $3^{\prime}$

\section{PCR conditions:}

LA Taq polymerase (Takara Mirus)

1. $94^{\circ} \mathrm{C}-2 \mathrm{~min}$

2. $98^{\circ} \mathrm{C}-10 \mathrm{sec} / 58^{\circ} \mathrm{C}-15 \mathrm{sec} / 68^{\circ} \mathrm{C}-1$ min 30 cycles

3. $72^{\circ} \mathrm{C}-7 \mathrm{~min}$

Amplicons:

4. Cool down at $4^{\circ}$

$$
\text { w.t allele: } \quad \sim 0.49 \mathrm{~kb}
$$$$
\text { m.t allele: } \quad \sim 0.62 \mathrm{~kb}
$$

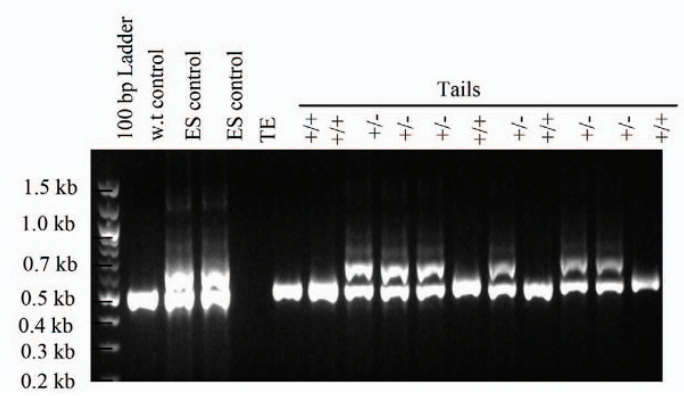

C

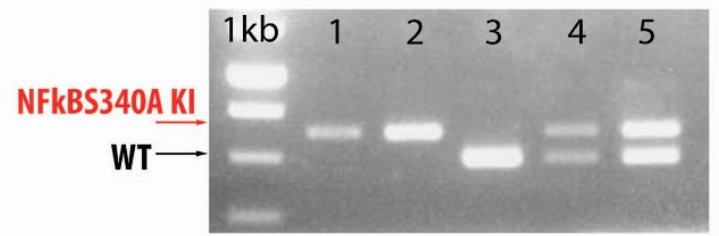

\section{Supplementary Figure 6}

(c) (i) This work is licensed under a Creative Commons Attribution 4.0 International License. The images or other third party material in this article are included in the article's Creative Commons license, unless indicated otherwise in the credit line; if the material is not included under the Creative Commons license, users will need to obtain permission from the license holder to reproduce the material. To view a copy of this license, visit http://creativecommons.org/licenses/by/4.0/ 